\title{
A Study on the Characteristics and Transmission Ways of China Central Plain Opera Culture
}

\author{
Xinyu Li \\ Henan University of Animal Husbandry and Economy, Zhengzhou City, Henan Province, 450046, \\ China
}

Keywords: China Central Plain Culture; Opera culture; Characteristics; Transmission

\begin{abstract}
China Central Plain Culture is broad and profound, and it has promoted the transformation of the central plain drama. In turn, the China central plain opera culture has become the driving force of the China central plain culture, and plays an irreplaceable role in the prosperity, inheritance and development of the China central plain culture. Based on the author's learning and practical experience, this paper first analyzes the characteristics of the China central plain opera culture, then put forward the ways to spread China central plain opera culture. The research results of this paper are helpful to analyze the cultural characteristics of China ventral plain opera, and have a certain contribution to the spread of the Chinese opera culture.
\end{abstract}

\section{Introduction}

China Central Plain Culture is the general term of mass culture and spiritual culture in the China Central Plains, and it is also the mother and the backbone of Chinese culture. The budding of the traditional opera art has already appeared in the Song and Jin Dynasty and it has undergone quite a long period of development[1]. Based on the folk song and dance, rap music and comic opera, it formed a relatively complete form of opera. The Chinese traditional opera in the Central Plains has the characteristics of early origin, variety and great influence, among many kinds of opera, Henan Opera is the most representative one in the China Central Plain Opera.

\section{Characteristics of China Central Plain Opera Culture}

Almost all Chinese traditional opera come from the folk with a strong local flavor. Shallow white, pop melodies, perform properly are the characteristics of China Central Plain Opera Culture. It is similar to the farmer's life in order to reflect the lives of ordinary people and takes small household affairs story as the theme, so it is easy to understand and easy to spread. Innovative interpretation of different communities makes it closer to the local local customs and practices. The creators of the Central Plains Opera is usually unknown, because it can not be a writer independent creation. It is often derived from the lives of the masses, and the writers often absorb the recommendations of ordinary people, in particular, after the performance and exchange with the masses, the Central Plains became a unique way in creative processing. Theatrical actors often listen to other famous fans' suggestions, after continuous polishing, integration, the folk culture has been enriched and developed along with the change of the times. The characteristics of this folk creation determines the difference between different parts of the same type in different societies when performing. The 
characteristics of folk art determine its wide applicability, and these writers make the drama lines more elegant when writing, so that the opera literature level has been significantly improved. The author's own living space make them consciously keep opera popular features in creation, while people's enjoy and identity determine the inevitability of these opera aesthetic secularization.

The Central Plains opera has a smooth melody and the strong local features singing has reduced the distance between the ordinary people and the central opera. Personality characteristics of Chinese opera stories is fair, reasonable and easy to learn, and the cultivation for truth, goodness and beauty can make the audience be educated in the study, singing and entertainment. The initial development of the Central Plains of Henan Opera spread in the folk, and it is usually sung orally. Because there is no music and spectrum, the concert usually cultural level is not high, the opera tradition mainly relies on the master's words and deeds. In the process of singing, there is no fixed pattern of singing, so the concert or learners can often innovate singing according to local customs or personal conditions. From this perspective, the central opera sung has great flexibility and uncertainty, and as time goes by, singing lyrics can be changed and is constantly changing. Affected by the local traditions and customs, this change is only reflected in different regions and different groups and it can not be arbitrarily changed, showing some stability.

Same as the folk amateur opera group, mass activities of traditional opera rise up in the late twentieth century. It has made up for the shortage of the professional groups in the mass communication with the amateur groups, formed a kind of opera culture, became a unique landscape of modern city. The opera performances have many forms, such as performances, community performances, teahouse performances and party performance and so on. Private troupes and state owned art troupes shoulder the task of developing the market and enriching the cultural life of the people. The troupe has long been active in the countryside, towns, mines, enterprises, so they are the most basic cultural communicators and art communicators[2]. It has made some contribution to the active performance market and met the people's cultural life. Of course, there are a lot of problems in the survival of the opera troupes, such as talent fault, funding constraints, difficult to arrange in the big environment. As a department of government culture, we should pay close attention to and support the survival and development of private troupes. From another point of view, the awareness of the private troupes, business model, management system can provide some useful experience for the innovation and reform of state-owned art performing groups to some extent.

With the development of the times, opera itself pays attention to the combination of the unique local artistic features and the China Central Plain cultural spirit in innovation, and make the art form with regional restrictions develop into mass culture. The opera has absorbed the central spirit of the Central Plain Culture in its development, and combined the traditional opera culture with the spiritual quality of human beings. Central Plain culture has a long history and heavy accumulation with enduring vitality. In the development of the opera, the essence of this culture will be absorbed into the art of opera, continuing to highlight the popularity of opera culture. In the development of opera, it did not focus on the Central Plain, and the creation of the Central Plain drama also stressed the absorption of other provinces' opera culture, so the opera is a local drama with a strong local 
characteristics, but the drama is good at absorbing and melting of exotic tunes, which is its exuberant life and widespread source.

\section{The ways to Spread China Central Plain Opera Culture}

According to the combination of theory and practice, the combination of history and reality to take a historical investigation and realistic comparison of the development of folk opera in the Central Plain based on a in-depth investigation, analysis and research, then it can put forward the guiding ideology, basic principles and main countermeasures for the construction of folk art in China Central Plain.

Combined with the actual situation of the development of rural folk opera art, to put forward the new measures for the development of folk opera culture in China Central Plain, establish and perfect the mechanism, policy and system of rural folk opera art and optimize the environment of the development of rural folk opera[3]. Combined with the characteristics and advantages of the development of folk opera art in some areas of China Central Plain, we can cultivate a contingent of folk opera talents with moderate scale, reasonable structure, good quality and full vitality, bring up a number of high-level folk opera art talent and team, to achieve high-end lead in some areas with developed folk opera art.

The construction of new rural folk opera art talent team is a systematic project, which needs to be incorporated into the overall planning of the national economy and social development. It is necessary for the whole society to establish a series of policies and systems for the new rural folk opera art team; The evaluation and incentive system of the talent construction of folk opera art should be perfect; Improving and improving the conditions and environment for the growth and development of folk opera; It needs to gradually expand the cultivation of the talents of folk opera art, and constantly improve the professional skills of folk opera art talents. Music lessons in primary and secondary schools can also cultivate students' interest in opera, so that the children will begin to come into contact with local opera, local opera culture, and in this way we can cultivate their interest in opera culture. This can cause the attention of the people, so that China Central Plain folk opera art can get the whole society's attention.

China Central Plains is the hometown of opera, and the spread of folk opera can be roughly divided into standard and extended communication. Standard communication is the most direct transmission for the traditional opera art, is the first level of traditional opera. Extended communication is a spread of all kinds of information on the basis of traditional opera, is the second levels of traditional opera. Study and deal with the relationship between the two levels of traditional opera communication is helpful to the excavation of the new field of opera research and the protection and survival of traditional opera art[4]. In a sense, folk opera is to survive in the dissemination, and facing thick folk opera cultural resources in China Central Plain, how to protect, excavate, spread and develop it is an important problem in front of each of our artists. Therefore, communication is related to the survival of opera art. In recent years, in order to find a new way to inherit the traditional Chinese opera culture, Henan TV drama program founded Liyuanchun, which is a TV variety show based on the local opera in China Central Plain. The expression of the Chinese 
opera culture in China Central Plain is transformed into TV, so that the China Central Plain opera has a convenient and effective way to spread with the aid of television.

Acknowledgement

\section{Conclusion}

Dramas in the China Central Plain plays an important role in Chinese traditional culture, and the opera in the China Central Plain is one of the most important members. When we consider folk opera as a kind of cultural phenomenon but not a artistic skill, we'll find that the drama in the China Central Plain has a profound tradition of non commodity art and it has blended people's state of mind. The art of traditional opera has a long tradition of folk oral art with a fragrance of the earth, so we should better protect and inherit this kind of art, to make it flourish and send out a strong aroma

\section{Acknowledgement}

The research was supported by the fund project: Science and technology innovation team Research on the construction of China Central Plain culture(Henan University of Animal Husbandry and Economy).

\section{References}

[1] Feng Hui. Inheritance and development of folk opera culture in the Central Plains. People's forum,36, pp.132-133, 2010.

[2] Jia Tao. The Central Opera Culture and Kaifeng zhuxiantown woodcut New Year paintings. Journal of Southeast University (PHILOSOPHY AND SOCIAL SCIENCES EDITION), 01, pp.126-130, 2014.

[3] Han Yunxia. The influence of the Central Plains opera on the formation of Uygur drama. Journal of Xinjiang Arts Institute,03, pp.69-72, 2005.

[4] Li Ke. On the cultural choice of the Chinese opera in the Central Plains. Drama Art, 03, 47-50, 2003. 